\title{
Changing spaces of education: New perspectives on the nature of learning
}

By Rachel Brooks, Alison Fuller and Johanna Waters (eds.). Routledge, Abingdon and New York, 2012, 266 pp. ISBN 978-0-415-67221-4 (hbk), ISBN 978-0-415-67222-1 (pbk), ISBN 978-0-203-12756-8 (e-book)

\section{Michael McVey}

Published online: 18 January 2014

(C) Springer Science+Business Media Dordrecht and UNESCO Institute for Lifelong Learning 2014

Fundamental changes in international educational policies, increasingly porous borders and new communication technologies are changing the physical nature of schools and learning and, as a result, researchers and scholars must find new perspectives to frame their work.

The editors of this lively collection of essays have categorised the discussions and debates over new educational space into four areas: 1) international/ transnational spaces, 2) new policy spaces, 3) lifelong learning and work spaces, and 4) cyber-spaces and virtual learning. These themes work on the broadest definitions of education and learning. By drawing on examples and expertise from international perspectives, the editors hope to transcend narrow questions and examine broader trends.

Education takes place now in homes and workplaces, across national boundaries and in cyberspace. It also crosses traditional life stages. The editors of this collection argue that these diverse and fluid spaces are an important part of the reconfiguration of education in the 21 st century. They raise concerns about the potential effects of differential access to spaces of learning and see that space is becoming a social experience.

\section{International/transnational spaces of education}

As students cross boundaries and borders, injecting money into economies, the combination of instant communication and cheap travel are making higher education into a global marketplace.

Johanna Waters and Rachel Brooks urge us to explore more thoroughly the transnational relationships of mobile students. They also ask us to consider the

M. McVey (ه)

Eastern Michigan University, Ypsilanti, MI, USA

e-mail: mmcvey@emich.edu 
cultural capital accumulated through educational migration and further ask us to consider the social relationships of the students. Far from being the stereotypical carefree and individualistic student, they often fold into complicated societal structures that later may devolve into permanent immigration. The lives of these transnational students are deeply enmeshed in such complications and the resulting social development is worth greater study.

Kate Geddie focuses on international branch campuses, particularly in the United Arab Emirates. She touches on the increasing complexity of credentials coming out of this new shift of space. Mary Haden explores international schools and the children who attend them-global nomads from professional families and their third culture $k i d s$, as she calls them. She outlines the effect of these seemingly rootless lives.

\section{New policy spaces of education}

Changes affecting higher education in Europe wrought by the Bologna Process and the Lisbon Initiative are the focus in this chapter.

Laura C. Engel analyses policymaking in the European Union and sees potential in regional engagement and education governance. Molly Warrington contrasts this position by noting a move to centralisation in England, an approach that is proving to be unresponsive to local needs. Meanwhile, John Horton and Peter Kraftl see modest transformations in locally scaled practices within individual schools. By focusing on case studies where schools are redesigned, they find evidence of powerful transformation with pupil engagement in the change process that transcends national policies.

\section{Lifelong learning and work spaces of education}

The authors of this set of essays suggest that even during compulsory education the boundaries between learning, work, and leisure have become blurred.

Alan Felstead and Nick Jewson focus on the ways technology has shifted employment from fixed locations such as assembly lines or office buildings to more fluid spaces including home environments. New demands on workers create new demands on learning. Self-motivation and independent learning, they argue, should lead to new forms of self-governance and a change in the relationship between employers and employees.

Günter Hefler and Jörg Markowitsch take the next step and focus on employees' participation in formal adult education. They introduce the concepts of "organizational space" as defined by the employer and a "skills space" where the dominant training system sets the norms. The authors use these concepts and a huge data set to understand the roles of varying types of formal adult education. Authors Natasha Kersh, Edmund Waite and Karen Evans examined the physical location of training locations and found some, usually workplace training environments, to be more conducive to learning than others. This might be due to the fact that work settings offer more opportunities for practising, embedding and contextualising skills. 


\section{Cyber-spaces and virtual learning}

The influence of technology is more apparent as the authors move their examination of the concept of space from broad national policies to work-related issues coming closer to the individual learner. Changing conceptions of private versus public sectors of education wrought, in part, by e-learning are challenging the concept of learning at formal schools or in workplaces.

Richard Edwards eloquently noted that despite technologies that facilitate mobility, educational practices, domains and disciplines still exist which have moored the growth of these capabilities. Gráinne Conole sees hope for education in openness through open design, open delivery, open evaluation and open research. Socially enabled research techniques have created a more constructivist attitude towards educational practices but there is still a profound and significant distance to overcome because of differences in the digital literacy of learners. Finally, Francis Collins reminds the reader that communication technologies are bringing a sense of comfort and home to students who have physically crossed borders in their search for education.

New spatial formations of students, in effect, new geographies of learning, will continue to have an impact on educational policies both nationally and internationally. This collection of essays offers suggestions and guidance in how to study and perhaps manage these changes. 